\title{
A guide to enteral nutrition in intensive care units: 10 expert tips for the daily practice
}

\author{
Jean-Charles Preiser ${ }^{1 *} \mathbb{D}$, Yaseen M. Arabi ${ }^{2} \mathbb{B}$, Mette M. Berger ${ }^{3} \mathbb{B}$, Michael Casaer $^{4} \mathbb{B}$, Stephen McClave ${ }^{5}$, \\ Juan C. Montejo-González ${ }^{6}$, Sandra Peake ${ }^{7,8}$ (D) Annika Reintam Blaser ${ }^{9,10}$ (D) Greet Van den Berghe ${ }^{4}$, \\ Arthur van Zanten ${ }^{11}$ (D), Jan Wernerman ${ }^{12}$ and Paul Wischmeyer ${ }^{13}$ (1)
}

\begin{abstract}
The preferential use of the oral/enteral route in critically ill patients over gut rest is uniformly recommended and applied. This article provides practical guidance on enteral nutrition in compliance with recent American and European guidelines. Low-dose enteral nutrition can be safely started within $48 \mathrm{~h}$ after admission, even during treatment with small or moderate doses of vasopressor agents. A percutaneous access should be used when enteral nutrition is anticipated for $\geq 4$ weeks. Energy delivery should not be calculated to match energy expenditure before day 4-7, and the use of energy-dense formulas can be restricted to cases of inability to tolerate full-volume isocaloric enteral nutrition or to patients who require fluid restriction. Low-dose protein (max $0.8 \mathrm{~g} / \mathrm{kg} /$ day) can be provided during the early phase of critical illness, while a protein target of $>1.2 \mathrm{~g} / \mathrm{kg} /$ day could be considered during the rehabilitation phase. The occurrence of refeeding syndrome should be assessed by daily measurement of plasma phosphate, and a phosphate drop of $30 \%$ should be managed by reduction of enteral feeding rate and high-dose thiamine. Vomiting and increased gastric residual volume may indicate gastric intolerance, while sudden abdominal pain, distension, gastrointestinal paralysis, or rising abdominal pressure may indicate lower gastrointestinal intolerance.
\end{abstract}

Keywords: Critically ill, Stress response, Energy metabolism, Muscle wasting, Sarcopenia, Refeeding syndrome, Gastrointestinal dysfunction

\section{Introduction}

The importance of nutrition in the critically ill is increasingly acknowledged, especially in patients with long stay in the intensive care unit (ICU), who often require prolonged life-sustaining support and go through a state of severe catabolism $[1,2]$. Some aspects of the nutrition practice such as the preferential use of the early oral/ enteral nutrition (EN) over «gut rest» and the acceptance of delaying provision of amounts of nutrients calculated to match the losses and expenditure, while other aspects can raise controversial views [3-5].

\footnotetext{
*Correspondence: jean-charles.preiser@erasme.ulb.ac.be

1 Erasme University Hospital, Université Libre de Bruxelles, 808 Route de Lennik, 1070 Brussels, Belgium
}

Full list of author information is available at the end of the article
International guidelines have been recently updated by the American Society of Parenteral and Enteral Nutrition/Society of Critical Care Medicine [6] and the European Society of Clinical Nutrition and Metabolism (ESPEN) [2, 7], with various levels of supporting evidence (Table 1). A group of experts in critical care nutrition from different regions of the world was commissioned to discuss some of the practicalities of early EN, listed in Table 1 and supported in the corresponding sections, to use and to complement the guidelines $[6,7]$ by providing tips inspired by the current knowledge and clinical experience of the experts. Importantly, nutritional requirements will vary according to the phase of critical illness, our tips are general in nature, and an individualized approach should always be used.

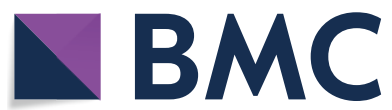

(c) The Author(s) 2021. Open Access This article is licensed under a Creative Commons Attribution 4.0 International License, which permits use, sharing, adaptation, distribution and reproduction in any medium or format, as long as you give appropriate credit to the original author(s) and the source, provide a link to the Creative Commons licence, and indicate if changes were made. The images or other third party material in this article are included in the article's Creative Commons licence, unless indicated otherwise in a credit line to the material. If material is not included in the article's Creative Commons licence and your intended use is not permitted by statutory regulation or exceeds the permitted use, you will need to obtain permission directly from the copyright holder. To view a copy of this licence, visit http://creativecommons.org/licenses/by/4.0/. The Creative Commons Public Domain Dedication waiver (http://creativeco mmons.org/publicdomain/zero/1.0/) applies to the data made available in this article, unless otherwise stated in a credit line to the data. 


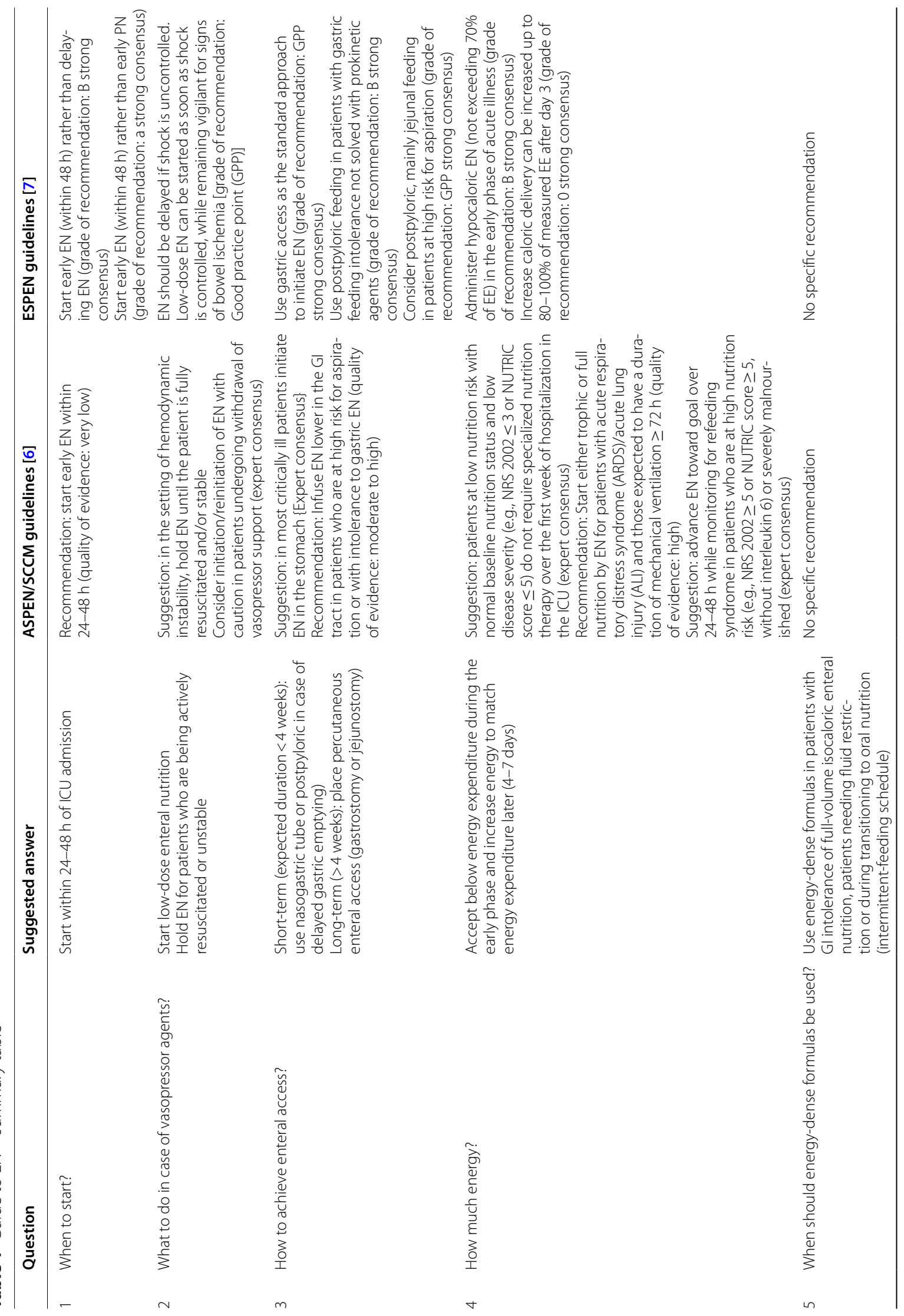




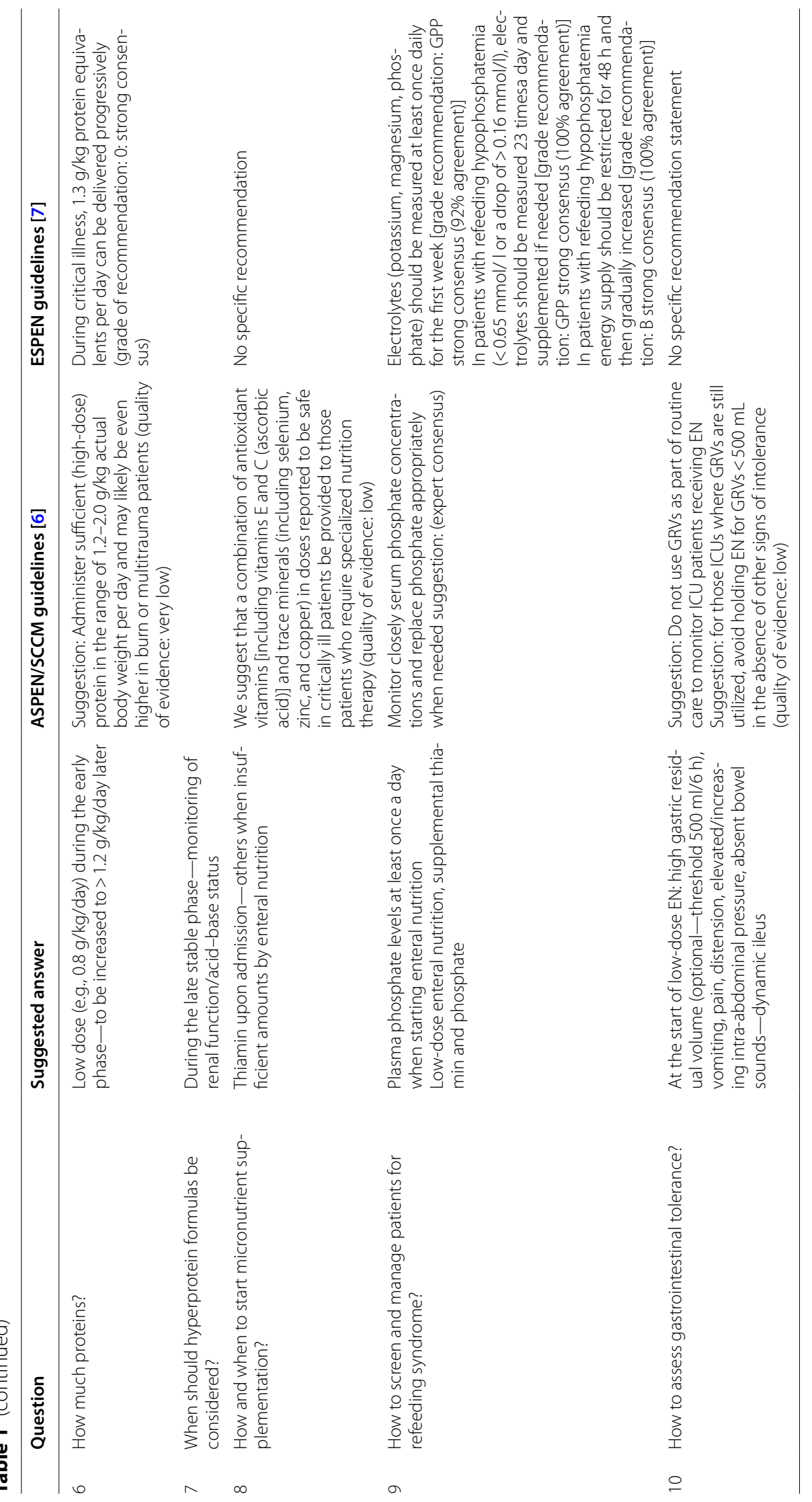




\section{Question 1: When to start?}

Critically illness induces a cascade of metabolic and hormonal derangements, leading to severe macro- and micronutrient deficiencies [8]. The provision of exogenous nutrients via early commencement of EN helps mitigate this catabolic state and prevent intestinal villi atrophy, enterocyte apoptosis, inflammatory infiltration, dysbiosis and impairment of gut immune functions [9]. Early EN may alleviate or even reverse some of these pathophysiologic cascades [10-12]. Clinical data have also supported early EN (within 24-48 h of ICU admission) in critically ill patients. Multiple meta-analyses of randomized controlled trials showed that early EN compared to late EN was associated with reduced infectious morbidity in ICU patients [5, 6, 13]. However, several of the studies were of small sample sizes, and some were conducted more than 3 decades ago, with different standards of ICU management and nutritional therapy. Additionally, some of the older trials have important methodological limitations questioning their internal validity including selection bias, frequent postrandomization exclusions and lack of adherence to the intentionto-treat principle. A recent Cochrane meta-analysis assessed current evidence to be of very low quality, leading to uncertainty as to whether early EN, compared with delayed EN, affects the risk of mortality, feed intolerance or gastrointestinal complications, or pneumonia [14].

In spite of the low level of evidence, recent guidelines $[6,7]$ recommend the commencement of low-dose EN within 24-48 h of critical illness in the majority of ICU patients.

\section{Question 2: What about EN in patients receiving vasopressor agents?}

Patients receiving vasopressor agents represent a special group, in which the potential benefit of early EN should be balanced against the associated risk [15-17]. Some data suggest that trickle feeding is possible even with high dose norepinephrine [18]. Data regarding the clinical benefits and risks of early EN in patients on vasopressor agents are limited. Although several observational data described an association between early EN and bowel ischemia, establishing causality between vasopressor agents and bowel ischemia in these studies is difficult [19-21]. In the NUTRIREA-2 trial, adults receiving mechanical ventilation and vasopressor agents were randomized to either early parenteral nutrition $(\mathrm{PN})$ or $\mathrm{EN}$, both at rates calculated to match the energy expenditure [22]. The study found no difference in the primary endpoint of 28-day mortality, but demonstrated a fourfold increase in bowel ischemia and acute colonic pseudoobstruction with early EN [22]. The study suggests that full dose EN should be postponed until hemodynamic stability is restored. Whether lower amounts of EN or no EN at all would be the best option in patients with severe shock is not known. Still, aggregated data from 11 randomized controlled trials (RCTs, $n=597$ ) show that early EN might decrease infectious complications [14] presumably via the protection of gastrointestinal wall integrity [23]. Nevertheless, in NUTRIREA-2 $(N=2410)$ and CALORIES $(N=2400)$, early EN as compared to PN for no more than 3-5 days did not decrease the infection rate $[22,24]$.

Several related questions are currently subject to ongoing research including comparing early trophic EN with no EN in the first 24 h [25-29].

Given the existing data, low-dose EN is recommended within $48 \mathrm{~h}$ of ICU admission, in patients with controlled shock requiring small or moderate doses of vasopressor and delaying $\mathrm{EN}$ in patients who are actively being resuscitated or are unstable $[5,6]$. In patients requiring vasopressors, EN should be started with gradual advancement, with monitoring for symptoms and signs of gastrointestinal intolerance or unexplained worsening hemodynamic status.

\section{Question 3: How to achieve enteral access?}

Decisions regarding enteral access are often determined by local expertise, anticipated duration of feeding, and evidence of gastroparesis or impaired gastrointestinal transit [30].

Short-term feeding may be facilitated by blind bedside placement of a nasogastric tube. Reliable aids to confirm location within the stomach include an abdominal radiograph, continuous $\mathrm{CO} 2$ monitor, or differential esophageal/tracheal compliance to intermittent suction [30].

The decision to switch from gastric to postpyloric feeding is based on perceived intolerance or delayed gastric emptying [7]. The placement of a postpyloric tube can be achieved endoscopic techniques, blind corkscrew technique, or GPS-guided or optically-guided tubes [30]. Use of a magnet-directed or flanged Tiger tube should be avoided. Surgical or radiologic techniques require transport to the operating room or radiologic suite, respectively. Randomized trials show a switch to postpyloric feeding reduces pneumonia significantly, but arguably no other outcome benefits are incurred, thereby underlying controversial views $[6,31,32]$. The decision to switch from nasoenteric to percutaneous access is predicated on an anticipated duration of feeding of greater than four weeks. A size of percutaneous endoscopic gastrostomy (PEG) tube larger than 18-20 French should be avoided, as torsion on the side wall leading to enlarged stomal diameter is more likely. Surgical placement of a gastrostomy tube is preferred in the presence of ascites, excluded 
stomach following bariatric surgery, or altered postoperative anatomy. Radiologic placement of a gastrostomy tube utilizes a variant of the "Introducer" technique.

The decision to attain deep jejunal access, such as converting a PEG to a PEGJ, is based on evidence of delayed gastric emptying [30,33]. A new PEG can be converted even at initial placement by shortening the length of the PEG and placing a second smaller jejunostomy tube (J-tube) through the PEG into the small bowel. A mature tract $(>7-10$ days since initial placement) is required to place a one-piece PEGJ, which affords a larger lumen for both feeding and aspiration.

\section{Question 4: How much energy?}

The concept of high enteral energy intake has been postulated and tested, but this strategy failed to improve vital -and long-term functional [34-36] outcome in large-scale RCT's [37-40]. These results suggest that disease-related anorexia contributes less to preventing lean-tissue wasting early in critical illness, than inflammation and mobilization. In some ICU patients, early up to target EN may moreover provoke harm. In patients recovering from circulatory shock, it provoked a small but significant increase in potentially lethal ischemic bowel complications [22]. Following a transitory decrease in serum phosphate, a feeding strategy aiming to achieve nutritional target increased mortality as compared to early nutrient restriction [41] (Question 9). Based on lack of benefit in large heterogeneous populations and signals of harm in some studies, ESPEN guidelines advise against early rapid advancement of feeding to target EN [7].

The individualization of intakes rather than aiming for enhanced or more restrictive feeding, equally applied to all patients might physiologically make more sense. Several scores-integrating clinical characteristics upon ICU admission and/or biomarkers-have been constructed in order to identify patients who might benefit from earlier or enhanced nutrition support. In particular, the value of the NUTRIC (The Nutrition Risk in the Critically Ill) score appeared promising for that purpose in observational analyses [42], but was refuted in stratified subanalysis of the PERMIT-RCT [43]. Indirect calorimetry (IC) provides accurate estimation of energy burned by patients at rest [7]. IC-guided nutrition therapy, however, did not convincingly improve outcomes, in the absence of methodologically sound evidence [44-47]. The individualization of feeding based on a biomarker is not yet validated $[48,49]$.

While the impact of early nutrition interventions in ICU appears to be limited, nutrient provision during inICU rehabilitation and after ICU discharge is unexplored and potentially relevant to functional recovery $[1,50,51]$.
In summary, energy intakes should be lower than energy expenditure during the early phase (4-7 days) and are increased to match energy expenditure later.

\section{Question 5: When should energy-dense formulas be used?}

The macro- and micronutrient content of EN differs between various formulations. While isocaloric EN $(1 \mathrm{kcal} / \mathrm{ml})$ is commonly prescribed to achieve estimated or measured caloric goals [52-54], energy-dense formulae $(>1 \mathrm{kcal} / \mathrm{ml})$ are also available. The increase in energy is achieved with increases in the proportion of mainly factor, carbohydrate.

The most common reasons for prescribing an energydense formulation are either to increase calorie delivery in patients with gastrointestinal dysfunction, an inability to tolerate full-volume isocaloric EN, fluid restriction or transitioning to oral nutrition using an intermittent-feeding schedule (e.g., overnight) while ensuring adequate energy intake. However, several caveats exist.

First, higher osmolality and fat content in energydense formulations may further impair delayed gastric emptying via neurohumoral feedback mechanisms (e.g., cholecystokinin, glucagon-like peptide-1) and via duodenal osmoreceptors which decrease gastric emptying until the gastric and duodenal contents are iso-osmotic. These solutions might cause diarrhea via the stimulation of fluid secretion within the small intestine [55]. Finally, the delivery of energy-dense nutrition at a lower rate may have the unintended consequence of decreased water and protein administration.

Second, the early administration of an energy-dense formulation has not been shown to improve outcomes. A large study reported that a near $50 \%$ increase in calorie delivery with an energy-dense EN formulation did not improve mortality at any time point, organ support or 6-month quality of life and functional outcomes compared to a $1 \mathrm{kcal} / \mathrm{ml}$ formulation [36, 40]. Subgroup analysis also did not demonstrate any differences between the energy-dense and isocaloric EN groups. Energy-dense EN was associated with increased gastrointestinal intolerance and higher blood glucose levels.

\section{Question 6: How much protein?}

Patients' muscle mass at ICU admission is correlated with ICU survival and this serves as an endogenous metabolic or amino acid reserve $[4,8,56,57]$ (Fig. 1). The catabolic response leads to marked muscle mass loss of up to $1 \mathrm{~kg}$ per day over the first 10 days of ICU stay and is associated with ICU-Acquired Weakness [58]. Nitrogen losses increase fourfold within the first $24 \mathrm{~h}$ of ICU stay [59].

Current data consistently demonstrate that ICU patients receive low amounts of protein (average of $0.6 \mathrm{~g} /$ 


\section{Early Catabolic Response to Critical IIIness and Trauma}

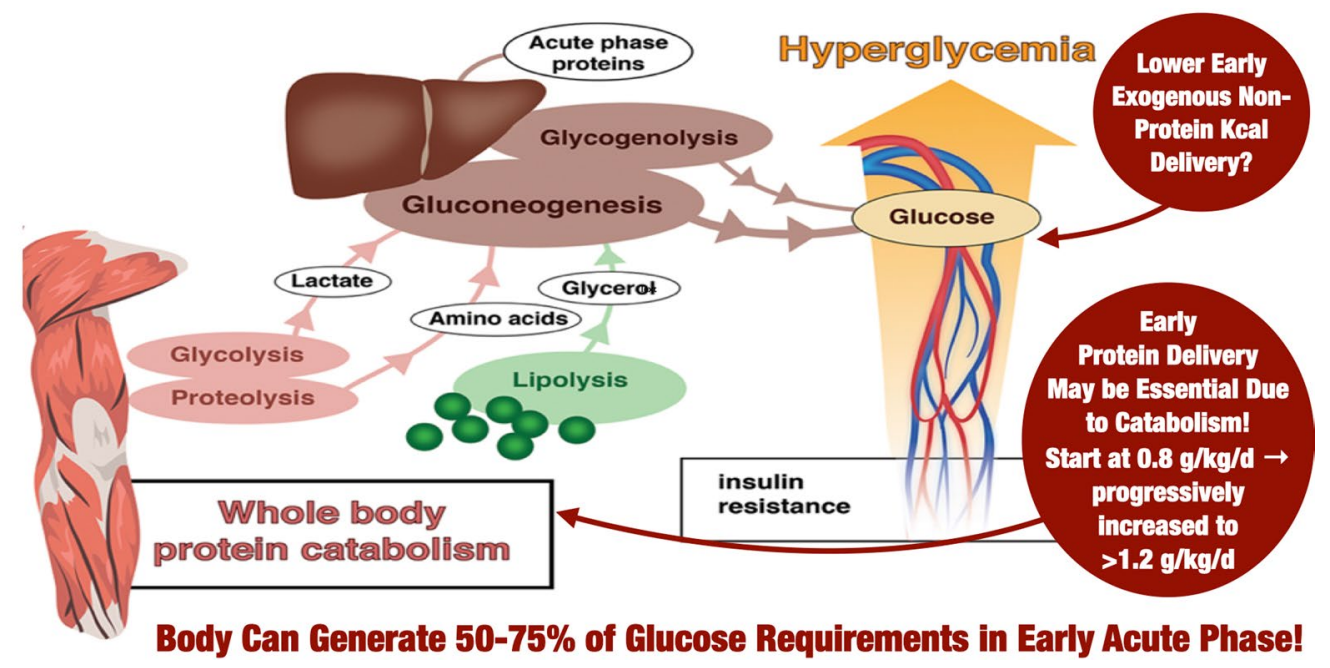

Fig. 1 Acute phase catabolic response to critical illness and need for protein and non-protein calories. Adapted from: Ref. [57]

$\mathrm{kg} /$ day for the first two weeks) [24, 60-67]. Higher protein provision is associated with reduced mortality in adults in observational trials [61, 68-74], biochemical outcome parameters and morphometric outcomes in skeletal muscle [75-79], improved quality of life at 3-month post-ICU [69] or handgrip strength at hospital day 7 and muscle mass [73]. However, prospective studies show limited effects on clinical, patient-centered and functional outcomes or yield negative results $[45,67,74-$ 81]. Admittedly, a limited number of large RCTs examined clinical outcomes of specifically increasing protein administration.

Hence, there is no evidence for a higher protein intake in critically ill patients in terms of clinically relevant outcomes in prospective randomized trials [82, 83]. Moreover, some harm can be related to excessive amounts of proteins in a post hoc analysis of prospective trials performed in adults $[45,84,85]$ or in children [86] and in a retrospective study [87]. Hence, it may be prudent to start protein delivery at a lower dose $(\sim 0.8 \mathrm{~g} / \mathrm{kg})$ and ramp up protein dose to the targeted protein goal $(>1.2-$ $1.3 \mathrm{~g} / \mathrm{kg} /$ day [6, 7] (Fig. 2). However, this strategy was not previously evaluated in prospective studies.

The role of high-protein intakes that stress the need for focused larger clinical trial evidence examining the effect of specifically increasing protein delivery [4, 67, 84], combined with active mobilization to optimize physical therapy and functional outcomes in long-stayers, requires further study. Importantly, muscle volume and strength are not necessarily related. Preliminary data suggest that the combination of neuromuscular electrical

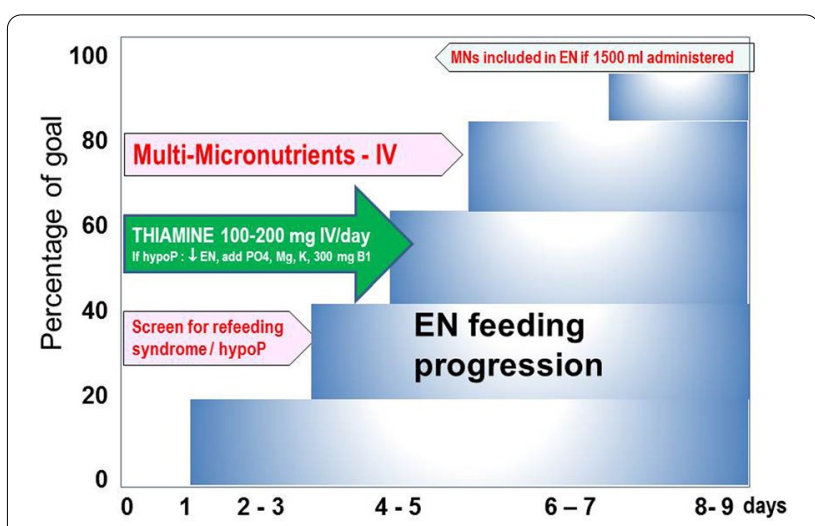

Fig. 2 Recommendations for the progression of enteral nutrition delivery, micronutrients delivery and management of refeeding. Adapted from: CHUV Lausanne and Gelderse Vallei Hospitals. The $X$ axis represents the time from admission (days, arbitrary example) and the $Y$ axis the percentage of nutritional goal determined by $a$ computer protocol using sex, height, weight (first 3 days) and later by indirect calorimetry or calculation prioritizing the avoidance of energy overfeeding. Regular (hourly) checks of intakes including the amount of non-nutritional energy (propofol, glucose, citrate) are recommended to adapt the infusion rate. Multi-micronutrients are administered IV until the dietary recommended intakes are met by the EN solution. The screening for refeeding syndrome is based on daily phosphate determination from day 2. In case of hypophosphatemia (hypoP) (serum phosphate (PO4) $<0.65 \mathrm{mmol} / \mathrm{l}$, or a drop from baseline $>0.16 \mathrm{mmol} / \mathrm{l}$ occurring within $72 \mathrm{~h}$ of the start of EN) decrease the amount of energy delivered to a maximum of $500 \mathrm{kcal} /$ day, supplement phosphate, magnesium $(\mathrm{Mg})$ and potassium $(\mathrm{K})$ and additional boluses of thiamine (vit B1, 500-1000 mg IV) 
stimulation and high-protein supplementation $(1.8 \mathrm{~g} / \mathrm{kg} /$ day) significantly improved short physical performance [88]. The role of high-dose protein delivery and in-bed ergometry (cycling) is being meaningfully studied [89] (NCT03021902).

\section{Question 7: When should hyperprotein formulas be used?}

There now exist a range of available high protein-toenergy ratio products intended to meet protein targets and non-protein calorie goals with a limited risk of overfeeding of non-protein calories. The use of enteral protein supplements or supplemental amino acid solutions (such as clear liquid whey protein formulas) is proposed for this purpose [90]. However, it is important to keep the amino acid composition well balanced. Nutrition regimens that are grossly unbalanced inflict a metabolic strain on the patient [91]. A high-protein product may be used in the later stable phase of critical illness [85]. However, there are no data from prospective randomized controlled studies with clinically relevant outcomes to support this recommendation.

Some potential alternatives include the addition of the leucine metabolite HMB (hydroxy methyl butyrate) to improve amino acid metabolism and reduce net protein breakdown [92].

A high-nitrogen intake should always be accompanied by daily monitoring of plasma concentration of urea and creatinine together with base excess. If plasma urea concentration is increasing, urea excretion in urine should be identified and followed by a decrease of protein intake and eventually renal replacement therapy. If base excess increases, always consider reducing protein intake. Acidosis may come in critically ill patients for several reasons, but when the renal compensatory mechanisms are overridden will the ability to eliminate a surplus of nitrogen be impaired.

\section{Question 8: When and how to start micronutrients?}

Ingestion of micronutrients (MN), i.e., trace elements and vitamins, is essential for normal metabolism [93], immunity [94], and antioxidant defense. They work as a web, and 24 of them are "essential," meaning that nutrition is the only source. The body stores of MNs are variable but generally insufficient to ensure normal metabolism beyond one week. The MNs needs will depend on the presence of prior deficiency, food intake before admission, particular body fluid losses, disease, and feeding rate. The available feeding products are meant to cover the needs of healthy people (dietary reference intakes) provided about $1500 \mathrm{kcal} /$ day is delivered to the patients [95]. However, these amounts are not integrating the specific requirements of critically ill patients. Intestinal function and absorption are often absent or depressed during the first days, and antioxidant stress is maximal [96].

Further, most recent guidelines [7] recommend that EN is started within $48 \mathrm{~h}$ of admission after stabilization [5] and progressed to target over 3-4 days (Fig. 2). Consequently, MN delivery starts at close to zero and remains below DRI for nearly a week, or "forever" in patients receiving less than $1500 \mathrm{kcal}$. It has been proposed to measure blood concentrations of some MN at risk [15]. The results of analysis are often not timely available and may be costly. As most patients stay briefly ( $<5$ days), there is no time to adapt to a delayed abnormal result. Nevertheless, blood values determination is rational for selected MNs depending on pathology and treatment when the patients stay more than a week, especially when renal replacement therapy is required [97-101].

Critically ill patients are often admitted with a nutritional deficit developed in the days preceding ICU admission, translating into $\mathrm{MN}$ deficiencies. The earliest manifestation is refeeding syndrome (RFS), with thiamine being in the first line discussed below [105]. The late complications are less specific, generally unrecognized, and sometimes called an "invisible foe" [110, 102-105]. Infections and wound healing complications are in the first line as $\mathrm{MN}$ are essential for immune defense. Therefore, during the early phase, as EN cannot cover the everyday needs and the higher needs associated with critical illness, early intravenous delivery of doses like those used in $\mathrm{PN}$ is rational (1 vial multitrace element and multivitamin $+100-200 \mathrm{mg}$ thiamine) (Fig. 2). A few trials have shown that the strategy to deliver MNs intravenously at doses 4-5 times higher than for PN until EN can cover the needs is associated with better global outcomes [106, 107].

\section{Question 9: How to screen and manage patients for refeeding syndrome?}

Refeeding syndrome (RFS) is a potentially fatal acute metabolic response following the reintroduction of nutrients after a variable length of starvation that may lead to morbidity and increased mortality [108].

Refeeding syndrome is characterized by electrolyte shifts that arise from a switch from a catabolic state using fat and protein as energy sources back to carbohydrate metabolism. Glucose substrate utilization leads to increased insulin levels, resulting in thiamine depletion and low plasma levels of phosphate, magnesium and potassium due to the intracellular shift of electrolytes [109-111]. The complications of RFS are so severe that the liberal administration of intravenous thiamine 100$200 \mathrm{mg} /$ day for the first 3 days should be part of routine (Fig. 2). In the absence of appropriate management, many 
clinical potentially life-threatening consequences may develop [108].

Due to significant variations in RFS definitions, its exact incidence remains unknown. However, when RFS is defined by hypophosphatemia (hypoP) with a cut-off level of $0.65 \mathrm{mmol} / \mathrm{L}$, the incidence ranges from 34 to $40 \%$, with $4-10 \%$ presenting severe hypophosphatemia (phosphate $<0.32 \mathrm{mmol} / \mathrm{L}$ ) or a drop after the start of glucose infusion or nutrition therapy [111-113]. Most recent studies in ICU patients using hypoP as the primary criterion to define RFS did not identify clinical predictors of RFS on ICU admission [41, 110, 114]. Therefore, all critically ill patients should be considered at risk of refeeding syndrome and monitored for serum phosphate levels at least once a day when starting EN [110]. The diagnostic criteria and recommendations to monitor phosphate have recently been adopted by the ESPEN nutrition guidelines [7].

Recent studies have demonstrated that high-energy intake during RFS is associated with increased mortality, and caloric restriction confers improved outcomes $[114,115]$. The difference in mortality occurred much later during patients' ICU stay after correction of electrolyte imbalance, suggesting a complex pathophysiology $[41,114]$. Thiamine administration and caloric restriction of $500 \mathrm{kcal} /$ day or $25 \%$ of the estimated target inspired from NICE guidance [116] is a frequent practice for ICU patients with hypoP/RFS for at least $48 \mathrm{~h}$.

Practical protocols are available on-line (e.g., [117]) to guide progressing energy to target in the early phase of ICU stay is provided. Energy target on admission is based on predictive equations. In 4 steps of $25 \%$, feeds are advanced to the estimated target to prevent overfeeding, including non-nutritional energy from propofol and citrate. Indirect calorimetry is performed to adjust to the actual energy expenditure and set as a new target. When refeeding hypoP within $72 \mathrm{~h}$ after the start of EN is encountered, caloric restriction is warranted. After $48 \mathrm{~h}$ subsequently, the following steps (25\%) are set.

\section{Question 10: How to assess gastrointestinal intolerance?}

Gastrointestinal (in)tolerance is often defined with certain symptoms/signs, with 'tolerance' meaning the absence of these symptoms and signs [118-120]. 'Enteral feeding intolerance' (EFI) is commonly defined as a certain amount of gastric residual volumes (GRV) [119-121], capturing only upper gastrointestinal (GI) problems after initiation of enteral tube feeding, while both upper and lower parts of the GI tract can be involved (Fig. 3). In most of available studies, patients with EFI were more severely ill compared to patients tolerating EN, suggesting that EFI could be an epiphenomenon or a marker of disease severity [118]. In several studies, the occurrence of EFI as a feature of GI dysfunction was shown to independently associate with adverse outcome, as an additional organ dysfunction [119, 121-124].

Gastric intolerance assessed by the GRV measurement is the prevalent gastrointestinal symptom in ICU patients treated with EN $[118,125,126]$. Measurements of GRV have been omitted in many sites since a study showed no benefit of GRV-guided EN in patients with already established EN despite vomiting occurred more often in patients without than with GRV measurements [127]. However, the relation of GRV with the tracheal aspiration of gastric contents and pneumonia development is not clear [128, 129] and GRV measurement is a timeconsuming practice and is associated with infectious risk (COVID-19) and variability in practices [121, 122]. Due to these factors and uncertainties, recent guidelines either do not recommend routine measurement of GRV [6], or suggest restricting GRV measurements to the initiation and progression of EN only [5, 7]. The latter is important, as evidence from RCTs is available only for medical patients having full EN already established at study inclusion [126]. Moreover, there is no good substitute for GRV, which could be considered as a surrogate marker of gastric emptying at bedside [128]. Therefore, depending on local constraints, GRV can still be included in assessment of EFI and a GRV over $500 \mathrm{ml} / 6 \mathrm{~h}$ is considered as an indication for intervention (delay or interruption of EN or application of prokinetics) [129]. [5, 7, 130-133], even though prokinetics has not been proven to improve patient-relevant outcomes [134].

Lower parts of GI tract are often involved, even in the absence of upper GI intolerance. Lower GI intolerance requires different management. Bowel paralysis leading to bowel distension in patient receiving EN may be associated with adverse outcomes. Patients in shock receiving early full EN compared to PN more often developed Ogilvie's syndrome and bowel ischemia [22]. Monitoring and management of EFI and GI dysfunction is complicated due to the lack of robust and reproducible markers and multifaceted clinical presentation [49]. As no single straightforward marker reliably detects GI dysfunction, using composite scores combining several symptoms and signs could be helpful and should be considered [131]. EFI at the bedside is defined as features of GI dysfunction appearing during EN and consequently leading to reduction or discontinuation of EN. [123, 124, 135] Evidence on management options, unanswered issues and proposals for future research on GI dysfunction have been recently summarized [136]. In brief, patients should be carefully assessed for high gastric residual volume (optional-threshold $500 \mathrm{ml} / 6 \mathrm{~h}$ ), vomiting, pain, 


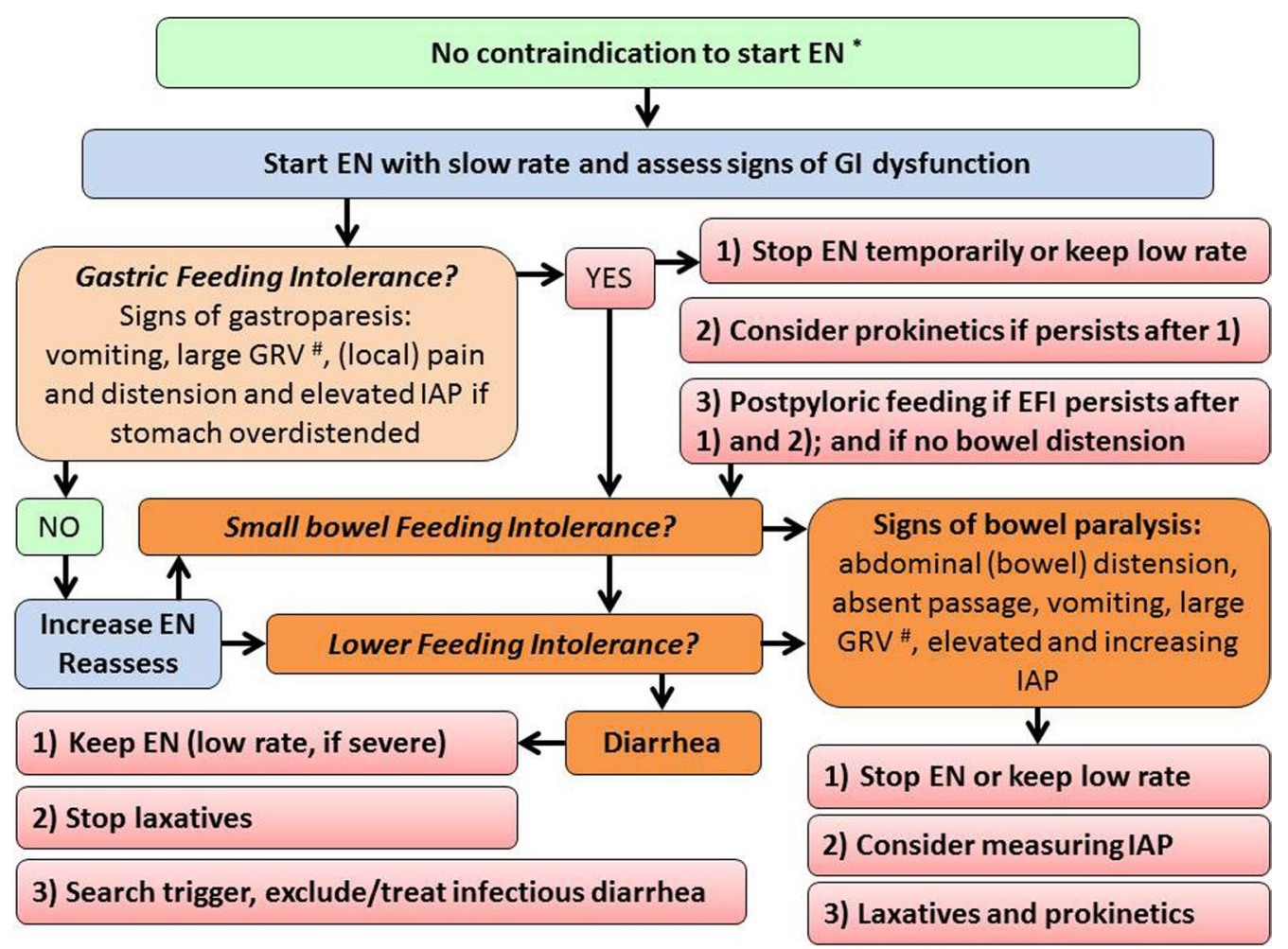

Fig. 3 Screening for enteral feeding intolerance (ARB). Differentiation between EFI in different parts of GI tract and respective terminology has not been uniformly established. *Suggested contraindications to EN are uncontrolled shock, uncontrolled hypoxemia and acidosis, uncontrolled upper Gl bleeding, gastric aspirate $>500 \mathrm{ml} / 6 \mathrm{~h}$, bowel ischemia, bowel obstruction, abdominal compartment syndrome, and high-output fistula without distal feeding access. \# GRV between 200 and $500 \mathrm{ml}$ can be considered increased and $>500 \mathrm{ml}$ a cut-off for discontinuation of EN

distension, elevated/increasing intra-abdominal pressure, GI paralysis.

\section{Conclusions}

The importance of medical nutrition in the care of the critically ill cannot be overstated. Overall, the management of EN requires a systematic and updated approach involving all ICU professionals, including practical approaches proposed in this document and regular updates. Auditing changes in practice are needed locally from the entire community of ICU professionals to increase the safety and efficiency of the delivery of EN.

\section{Acknowledgements}

Not applicable.

\section{Authors' contributions}

JCP drafted the conception and design of this article, YMA drafted Sects. 1 and 2, SMC drafted Sect. 3, MC and GVdB drafted Sect. 4, SP drafted Sect. 5, PW and JW drafted Sects. 6 and 7, MB and AvZ drafted Sects. 8 and 9, and ARB and JCM drafted Sect. 10. All authors critically revised the manuscript and brought significant contributions to all sections. All authors read and approved the final manuscript.

\section{Funding}

None.
Availability of data materials

Not applicable.

\section{Declarations}

Ethical approval and consent to participate Not applicable.

\section{Consent for publication}

Not applicable.

\section{Competing interests}

Jean-Charles Preiser: speaker's and consultant's fee form Baxter, DIM-3, Fresenius, Nestlé HealthScience, Nutricia/Danone, VIPUN. Yaseen M. Arabi: Principal investigator on an investigator-initiated RCT for protein intake in critically ill patients (NCT04475666). Mette M. Berger: speaker fees from Abbott, Baxter, BBraun, DSM, Fresenius Kabi, Nestlé HealthScience, Nutricia/Danone. Michael Casaer: supported by the Research Foundation_Flanders, Belgium (Fundamental Clinical Research fellowship 1700111N;) and a KULeuven C2 Research Project Grant (C24/17/070) and received a speaker fee from Fresenius ( $\left.{ }^{\circ} 2020\right)$ and a consultant fee from Baxter ('2021). Stephen McClave,: none declared. Juan Carlos Montejo: speaker' and consultant's fees and research grants from Abbott, Baxter, Fresenius-Kabi, GE Healthcare, Nestlé HealthScience. Sandra Peake: none declared. Annika Reintam Blaser received speaker or consultancy fees from Fresenius Kabi, Nestlé and VIPUN Medical. University of Tartu received a study grant from Fresenius Kabi. ARB is one of the authors of ESICM guidelines on early enteral nutrition; ESPEN guidelines on clinical nutrition in the intensive care nutrition and BMJ rapid recommendations on the prophylaxis of gastrointestinal bleeding in critically ill. Greet Van den Berghe: funded by the Methusalem program of the Flemish Government (METH/08/07 which 
has been renewed as METH/14/06 via KU Leuven); the European Research Council (ERC) Advanced Grants (AdvG-2012-321670 from the Ideas Program of the EU FP7 and AdvG-2017-785809 from the Horizon 2020 Program of the EU) Greet Van den Berghe has no conflict of interest regarding this publication. Arthur van Zanten: speaker' and consultant's fees and research grants from Abbott, AOP Pharma, BBraun, Cardinal Health, Baxter, DIM-3, Fresenius-Kabi, GE Healthcare, Mermaid, Lyric, Nestlé HealthScience, Nutricia/Danone, Rousselot. Jan Wernerman: speaker's fees from GE Healthcare, Nestlé and Nutricia Danone, no conflict of intrest regarding this publication. Paul Wischmeyer: Dr. Wischmeyer reports receiving investigator-initiated grant funding related to this work from National Institutes of Health, Canadian Institutes of Health Research, Abbott, Baxter, and Fresenius. Dr. Wischmeyer has served as a consultant to Abbott, Fresenius, Baxter, Takeda, Gravitas, and Nutricia. Dr. Wischmeyer has received unrestricted gift donation for nutrition research from Musclesound and DSM. Dr. Wischmeyer has received honoraria or travel expenses for CME lectures on improving nutrition care from Abbott, Baxter, Danone-Nutricia and Nestle.

\section{Author details}

${ }^{1}$ Erasme University Hospital, Université Libre de Bruxelles, 808 Route de Lennik, 1070 Brussels, Belgium. ${ }^{2}$ Intensive Care Department, College of Medicine, King Saud Bin Abdulaziz University for Health Sciences and King Abdullah International Medical Research Center, Ministry of National Guard Health Affairs, Riyadh, Saudi Arabia. ${ }^{3}$ Adult Intensive Care, Lausanne University Hospital, CHUV, 1011 Lausanne, Switzerland. ${ }^{4}$ Clinical Department and Laboratory of Intensive Care Medicine, Department of Cellular and Molecular Medicine, Katholieke Universiteit Leuven, Leuven, Belgium. ${ }^{5}$ Department of Medicine, University of Louisville School of Medicine, Louisville, KY, USA. ${ }^{6}$ Intensive Care Medicine, Hospital Universitario, 12 de Octubre, Instituto de Investigación imas12, Madrid, Spain. 'Department of Intensive Care Medicine, The Queen Elizabeth Hospital, Woodville, SA, Australia. ${ }^{8}$ Department of Critical Care Research, Faculty of Medicine, Nursing and Health Sciences, Monash University, Melbourne, Australia. ${ }^{9}$ Department of Intensive Care Medicine, Lucerne Cantonal Hospital, Lucerne, Switzerland. ${ }^{10}$ Department of Anaesthesiology and Intensive Care, University of Tartu, Tartu, Estonia. ${ }^{11}$ Ede and Division of Human Nutrition and Health, Gelderse Vallei Hospital, Wageningen University and Research, Wageningen, The Netherlands. ${ }^{2}$ Division of Anaesthesiology and Intensive Care Medicine, Department of Clinical Science, Intervention and Technology, Karolinska Institutet, Stockholm, Sweden. ${ }^{13}$ Department of Anesthesiology and Surgery, Duke University School of Medicine, Durham, NC, USA.

Received: 26 August 2021 Accepted: 27 November 2021 Published online: 14 December 2021

\section{References}

1. Hoyois A, Ballarin A, Thomas J, Lheureux O, Preiser J-C, Coppens E, et al. Nutrition evaluation and management of critically ill patients with COVID-19 during post-intensive care rehabilitation. JPEN J Parenter Enteral Nutr. 2021. https://doi.org/10.1002/jpen.2101.

2. Barazzoni R, Bischoff SC, Breda J, Wickramasinghe K, Krznaric Z, Nitzan $D$, et al. ESPEN expert statements and practical guidance for nutritional management of individuals with SARS-CoV-2 infection. Clin Nutr. 2020;39:1631-8.

3. Preiser J-C, van Zanten ARH, Berger MM, Biolo G, Casaer MP, Doig GS, et al. Metabolic and nutritional support of critically ill patients: consensus and controversies. Crit Care. 2015;19:35.

4. Wernerman J, Christopher KB, Annane D, Casaer MP, Coopersmith CM, Deane AM, et al. Metabolic support in the critically ill: a consensus of 19. Crit Care. 2019;23:1-10.

5. Reintam Blaser A, Starkopf J, Alhazzani W, et al. Early enteral nutrition in critically ill patients: ESICM clinical practice guidelines. Intensive Care Med. 2017;43:380-98.

6. Taylor BE, McClave SA, Martindale RG, Warren MM, Johnson DR, Braunschweig C, et al. Guidelines for the provision and assessment of nutrition support therapy in the adult critically ill patient: Society of Critical Care Medicine (SCCM) and American Society for Parenteral and Enteral Nutrition (ASPEN). Crit Care Med. 2016;44:390-438.
7. Singer P, Reintam Blaser A, Berger MM, et al. ESPEN guideline on clinical nutrition in the intensive care unit. Clin Nutr. 2019;38:48-79.

8. Preiser J-C, Ichai C, Orban J-C, Groeneveld ABJ. Metabolic response to the stress of critical illness. Br J Anaesth. 2014;2014:1-10.

9. McClave SA, Lowen CC, Rg M. The 2016 ESPEN Arvid Wretlind lecture: the gut in stress. Clin Nutr. 2018;37:19-36.

10. Buchman AL, Moukarzel AA, Bhuta S, Belle M, Ament ME, Eckhert $C D$, et al. Parenteral nutrition is associated with intestinal morphologic and functional changes in humans. JPEN J Parenter Enter Nutr. 1995; 19:453-60.

11. Nguyen NQ, Besanko LK, Burgstad C, Bellon M, Holloway RH, Chapman $M$, et al. Delayed enteral feeding impairs intestinal carbohydrate absorption in critically ill patients. Crit Care Med. 2012;40:50-4.

12. Hu Q, Ren H, Hong Z, Wang C, Zheng T, Ren Y, et al. Early enteral nutrition preserves intestinal barrier function through reducing the formation of neutrophil extracellular traps (NETs) in critically ill surgical patients. Oxid Med Cell Longev. 2020. https://doi.org/10.1155/2020/ 8815655.

13. Tian F, Heighes PT, Allingstrup MJ, Doig GS. Early enteral nutrition provided within 24 hours of ICU admission: a meta-analysis of randomized controlled trials. Crit Care Med. 2018;2018:1049-56.

14. Fuentes Padilla P, Martinez G, Vernooij RW, Urrutia G, Ifm R, Bonfill Cosp $X$. Early enteral nutrition (within $48 \mathrm{~h}$ ) versus delayed enteral nutrition (after 48 h) with or without supplemental parenteral nutrition in critically ill adults. Cochrane Database Syst Rev. 2019;2019:10.

15. Berger MM, Reintam-Blaser A, Calder PC, Casaer M, Hiesmayr MJ, Mayer K, et al. Monitoring nutrition in the ICU. Clin Nutr. 2019;38:584-93.

16. Arabi YM, Sa M. Enteral nutrition should not be given to patients on vasopressor agents. Crit Care Med. 2020;48:119-21.

17. Wischmeyer P. Enteral nutrition can be given to patients on vasopressors. Crit Care Med. 2020;48:122-5.

18. Berger MM, Berger-Gryllaki M, Wiesel PH, et al. Intestinal absorption in patients after cardiac surgery. Crit Care Med. 2000;28:2217-23.

19. Melis M, Fichera A, Mk F. Bowel necrosis associated with early jejunal tube feeding: a complication of postoperative enteral nutrition. Arch Surg. 2006;141:701-4.

20. Marvin RG, McKinley BA, McQuiggan M, Cocanour CS, Fa M. Nonocclusive bowel necrosis occurring in critically ill trauma patients receiving enteral nutrition manifests no reliable clinical signs for early detection. Am J Surg. 2000;179:7-12.

21. Mancl EE. Muzevich KM Tolerability and safety of enteral nutrition in critically ill patients receiving intravenous vasopressor therapy. JPEN J Parenter Enter Nutr. 2013;37:641-51.

22. Reignier J, Boisramé-Helms J, Brisard L, Lascarrou JB, Ait Hssain A, Anguel N, et al. NUTRIREA-2 trial investigators; clinical research in intensive care and sepsis (CRICS) group. Enteral versus parenteral early nutrition in ventilated adults with shock: a randomised, controlled, multicentre, open-label, parallel-group study (NUTRIREA-2). Lancet. 2018;391:133-43.

23. Piton G, Le Gouge A, Brule N, et al. Impact of the route of nutrition on gut mucosa in ventilated adults with shock: an ancillary of the NUTRIREA-2 trial. Intensive Care Med. 2019;45:948-56.

24. Harvey SE, Parrott F, Harrison DA, Bear DE, Segaran E, Beale R, et al. Trial of the route of early nutritional support in critically ill adults. N Engl J Med. 2014;371:1673-84.

25. Patel JJ, Kozeniecki M, Peppard WJ, Peppard SR, Zellner-Jones S, Graf J, et al. Phase 3 pilot randomized controlled trial comparing early trophic enteral nutrition with "no enteral nutrition" in mechanically ventilated patients with septic shock. JPEN J Parenter Enter Nutr. 2020;44:866-73.

26. Shah FA, Kitsios GD, Zhang Y, Morris A, Yende S, Huang DT, et al. Design of the study of early enteral dextrose in sepsis: a pilot placebocontrolled randomized clinical trial. JPEN J Parenter Enter Nutr. 2020;44:541-7.

27. El-Kersh K, Jalil B, McClave SA, Cavallazzi R, Guardiola J, Guilkey K, et al. Enteral nutrition as stress ulcer prophylaxis in critically ill patients: a randomized controlled exploratory study. J Crit Care. 2018;43:108-13.

28. Ye Z, ReintamBlaser A, Lytvyn L, et al. Gastrointestinal bleeding prophylaxis for critically ill patients: a clinical practice guideline. BMJ. 2020;368:16722. https://doi.org/10.1136/bmj.l6722.

29. Jalil BA, El-Kersh K. Enteral nutrition better than proton pump inhibitors? Curr Opin Crit Care. 2019;25:334-9. 
30. Itkin M, DeLegge MH, Fang JC, McClave SA, Kundu S, Janne d'Othee B, et al. Multidisciplinary practical guidelines for gastrointestinal access for enteral nutrition and decompression from the Society of Interventional Radiology and American Gastroenterological Association (AGA) Institute, with endorsement by Canadian Interventional Radiological Association (CIRA) and Cardiovascular and Interventional Radiological Society of Europe (CIRSE). Gastroenterology. 2011;141:742-65.

31. Alkhawaja S, Martin C, Butler RJ, Gwadry-Sridhar F. Post-pyloric versus gastric tube feeding for preventing pneumonia and improving nutritional outcomes in critically ill adults. Cochrane Database Syst Rev. 2015;2015(8):CD008875.

32. Deane AM, Dhaliwal R, Day AG, Ridley EJ, Davies AR, Heyland DK. Comparisons between intragastric and small intestinal delivery of enteral nutrition in the critically ill: a systematic review and meta-analysis. Crit Care. 2013;17:R125.

33. Tatsumi H. Enteral tolerance in critically ill patients. J Intensive Care. 2019;7:30.

34. Needham DM, Dinglas VD, Bienvenu OJ, et al. One year outcomes in patients with acute lung injury randomised to initial trophic or full enteral feeding: prospective follow-up of EDEN randomised trial. BMJ. 2013;346:f1532.

35. Needham DM, Dinglas VD, Morris PE, et al. Physical and cognitive performance of acute lung injury patients one year after initial trophic vs full enteral feeding: EDEN trial follow-up. Am J Respir Crit Care Med. 2013;188:567-76.

36. Deane AM, Little L, Bellomo R, et al. Outcomes six months after delivering $100 \%$ or $70 \%$ of enteral calorie requirements during critical illness (TARGET): a randomized controlled trial. Am J Respir Crit Care Med. 2020;201:814-22.

37. Rice TW, Wheeler AP, Thompson BT, et al. Initial trophic vs full enteral feeding in patients with acute lung injury: the EDEN randomized trial. JAMA. 2012;307:795-803.

38. Arabi YM, Tamim HM, Dhar GS, Al-dawood A, Al-sultan M, Sakkijha $\mathrm{MH}$, et al. Permissive underfeeding and intensive insulin therapy in critically ill patients : a randomized controlled trial. Am J Clin Nutr. 2011;93:569-77.

39. Arabi YM, Aldawood AS, Haddad SH, Al-Dorzi HM, Tamim HM, Jones G, et al. Permissive underfeeding or standard enteral feeding in critically ill adults. N Engl J Med. 2015;372:2398-408.

40. Chapman M, Peake SL, Bellomo R, et al. Energy-dense versus routine enteral nutrition in the critically ill. N Engl J Med. 2018;379:1823-34.

41. Doig GS, Simpson F, Heighes PT, Bellomo R, Chesher D, Caterson ID, et al. Restricted versus continued standard caloric intake during the management of refeeding syndrome in critically ill adults: a randomised, parallel-group, multicentre, single-blind controlled trial. Lancet Respir Med. 2015;3:943-52.

42. Heyland DK, Dhaliwal R, Jiang X, Day AG. Identifying critically ill patients who benefit the most from nutrition therapy: the development and initial validation of a novel risk assessment tool. Crit Care. 2011;15:R268.

43. Arabi YM, Aldawood AS, Al-Dorzi HM, et al. Permissive underfeeding or standard enteral feeding in high and low nutritional risk critically ill adults: post-hoc analysis of the permit trial. Am J Respir Crit Care Med. 2017;195:652-62.

44. Singer P, De Waele E, Sanchez C, et al. TICACOS international: a multicenter, randomized, prospective controlled study comparing tight calorie control versus Liberal calorie administration study. Clin Nutr. 2021:40:380-7.

45. Allingstrup MJ, Kondrup J, Wiis J, Claudius C, Pedersen UG, Hein-Rasmussen R, et al. Early goal-directed nutrition versus standard of care in adult intensive care patients: the single-centre, randomised, outcome assessor-blinded EAT-ICU trial. Intensive Care Med. 2017;43:1637-47.

46. Heidegger CP, Berger MM, Graf S, Zingg W, Darmon P, Costanza MC, et al. Optimisation of energy provision with supplemental parenteral nutrition in critically ill patients: a randomised controlled clinical trial. Lancet. 2013;381:385-93.

47. Casaer MP, Van den Berghe G, Gunst J. Indirect Calorimetry: a faithful guide for nutrition therapy, or a fascinating research tool? Clin Nutr. 2021:40:651.

48. Van Dyck L, Gunst J, Casaer MP, et al. The clinical potential of GDF15 as a "ready-to-feed indicator" for critically ill adults. Crit Care. 2020;24:557.
49. Stoppe C, Wendt S, Mehta NM, Compher C, Preiser JC, Heyland DK, et al. Biomarkers in critical care nutrition. Crit Care. 2020;24(1):499.

50. Ridley EJ, Parke RL, Davies AR, Bailey M, Hodgson C, Deane AM, et al. What happens to nutrition intake in the post-intensive care unit hospitalization period? An observational cohort study in critically ill adults. J Parenter Enter Nutr. 2019;43:88-95.

51. Massanet PL, Petit L, Louart B, Corne P, Richard C, Preiser JC. Nutrition rehabilitation in the intensive care unit. JPEN J Parenter Enteral Nutr. 2015:39:391-400.

52. Peake SL, Chapman MJ, Davies AR, et al. Enteral nutrition in Australia and New Zealand intensive care units: a point-prevalence study of prescription practices. Crit Care Resusc. 2012;14:148-53.

53. Ridley EJ, Peake SL, Jarvis M, et al. Nutrition therapy in Australia and New Zealand intensive care units: an international comparison study. J Parenter Enter Nutr. 2018:42:1349-57.

54. Preiser JC, Berré J, Carpentier Y, Jolliet P, Pichard C, Van Gossum A, et al. Management of nutrition in European intensive care units: results of a questionnaire. Working group on metabolism and nutrition of the European Society of Intensive Care Medicine. Intensive Care Med. 1999;25:95-101.

55. Kar P, Plummer MP, Chapman MJ, et al. Energy-dense formulae may slow gastric emptying in the critically ill. J Parenter Enter Nutr. 2016;40:1050-6.

56. Weijs PJ, Looijaard WG, Dekker IM, Stapel SN, Girbes AR, Oudemans-van Straaten HM, et al. Low skeletal muscle area is a risk factor for mortality in mechanically ventilated critically ill patients. Crit Care. 2014;18:1.

57. Gillis C, Carli F. Promoting perioperative metabolic and nutritional care. Anesthesiology. 2015;123:1455-72.

58. Puthucheary ZA, Rawal J, McPhail M, Connolly B, Ratnayake G, Chan $P$, et al. Acute skeletal muscle wasting in critical illness. JAMA. 2013;310:1591-600

59. Cresci GA. Protein and aminoacid metabolism: stress versus nonstress states. In: Cresci GA, editor. Nutrition support for the critically ill patient. Boca Raton: Taylor \& Francis; 2005. p. 29.

60. Weijs PJ, Cynober L, DeLegge M, Kreymann G, Wernerman J, Wolfe RR. Proteins and amino acids are fundamental to optimal nutrition support in critically ill patients. Crit Care. 2014;18:6.

61. Alberda C, Gramlich L, Jones N, Jeejeebhoy K, Day AG, Dhaliwal R, et al. The relationship between nutritional intake and clinical outcomes in critically ill patients: results of an international multicenter observational study. Intensive Care Med. 2009;35:1728-37.

62. Weijs PJM, Mogensen KM, Rawn JD, Christopher KB. Protein intake, nutritional status and outcomes in ICU survivors: a single center cohort study. J Clin Med. 2019;8:43.

63. Wischmeyer PE, Hasselmann M, Kummerlen C, Kozar R, Kutsogiannis DJ, Karvellas $C J$, et al. A randomized trial of supplemental parenteral nutrition in underweight and overweight critically ill patients: the TOP-UP pilot trial. Crit Care. 2017;21:142.

64. Yeh DD, Fuentes E, Quraishi SA, Cropano C, Kaafarani H, Lee J, et al. Adequate nutrition may get you home: effect of caloric/protein deficits on the discharge destination of critically ill surgical patients. JPEN J Parenter Enter Nutr. 2016;40:37-44.

65. Mitchell A, Clemente R, Downer C, Greer F, Allan K, Collinson A, et al. Protein provision in critically ill adults requiring enteral nutrition: are guidelines being met? Nutr Clin Pract. 2019;34:123-30.

66. De Waele E, Jakubowski JR, Stocker R, Pe W. Review of evolution and current status of protein requirements and provision in acute illness and critical care. Clin Nutr. 2021;40:2958-73.

67. Preiser J-C. High protein intake during the early phase of critical illness: yes or no? Crit Care. 2018;22:261.

68. Weijs PJM, Stapel SN, de Groot SDW, Driessen RH, de Jong E, Girbes ARJ, et al. Optimal protein and energy nutrition decreases mortality in mechanically ventilated, critically ill patients. J Parenter Enter Nutr. 2012;36:60-8

69. Wei X, Day AG, Ouellette-Kuntz H, Heyland DK. The association between nutritional adequacy and long-term outcomes in critically ill patients requiring prolonged mechanical ventilation: a multicenter cohort study. Crit Care Med. 2015;43:1569-79.

70. Nicolo M, Heyland DK, Chittams J, Sammarco T, Compher C. Clinical outcomes related to protein delivery in a critically ill population. $J$ Parenter Enter Nutr. 2016;40:45-51. 
71. Compher C, Chittams J, Sammarco T, Nicolo M, Heyland DK. Greater protein and energy intake may be associated with improved mortality in higher risk critically ill patients: a multicenter. Multinatl Observ Study Crit Care Med. 2017:45:156-63.

72. Zusman O, Theilla M, Cohen J, Kagan I, Bendavid I, Singer P. Resting energy expenditure, calorie and protein consumption in critically ill patients: a retrospective cohort study. Crit Care. 2016;20:367.

73. Elke G, Wang M, Weiler N, Day AG, Dk H. Close to recommended caloric and protein intake by enteral nutrition is associated with better clinical outcome of critically ill septic patients: secondary analysis of a large international nutrition database. Crit Care. 2014;18:R29.

74. Allingstrup MJ, Esmailzadeh N, Wilkens Knudsen A, Espersen K, Hartvig Jensen T, Wiis J, et al. Provision of protein and energy in relation to measured requirements in intensive care patients. Clin Nutr. 2012;31:462-8.

75. Hoffer LJ, Bistrian BR. Appropriate protein provision in critical illness: a systematic and narrative review. Am J Clin Nutr. 2012;96(3):591-600.

76. Tagawa R, Watanabe D, Ito K, Ueda K, Nakayama K, Sanbongi C, et al. Dose-response relationship between protein intake and muscle mass increase: a systematic review and meta-analysis of randomized controlled trials. Nutr Rev. 2020;79:66-75.

77. Ferrie S, Allman-Farinelli M, Daley M, Smith K. Protein requirements in the critically ill: a randomized controlled trial using parenteral nutrition. JPEN J Parenter Enteral Nutr. 2016:40:795-805.

78. Caparros T, Lopez J, Grau T. Early enteral nutrition in critically ill patients with a high-protein diet enriched with arginine, fiber, and antioxidants compared with a standard high-protein diet. The effect on nosocomial infections and outcome. JPEN J Parenter Enter Nutr. 2001;25:299-308.

79. Rugeles S, Villarraga-Angulo LG, Ariza-Gutiérrez A, Chaverra-Kornerup S, Lasalvia P, Rosselli D. High-protein hypocaloric vs normocaloric enteral nutrition in critically ill patients: a randomized clinical trial. J Crit Care. 2016;35:110-4.

80. Scheinkestel CD, Kar L, Marshall K, Bailey M, Davies A, Nyulasi I, et al. Prospective randomized trial to assess caloric and protein needs of critically III, anuric, ventilated patients requiring continuous renal replacement therapy. Nutrition. 2003;19:909-16.

81. Doig GS, Simpson F, Bellomo R, Heighes PT, Sweetman EA, Chesher $D$, et al. Intravenous amino acid therapy for kidney function in critically ill patients: a randomized controlled trial. Intensive Care Med. 2015:41:1197-208.

82. Davies ML, Chapple LS, Chapman MJ, Moran JL, Peake SL. Protein delivery and clinical outcomes in the critically ill: a systematic review and meta-analysis. Crit Care Resusc. 2017;19:117-27.

83. Fetterplace K, Gill BMT, Chapple LS, Presneill JJ, Maclsaac C, Deane AM. Systematic review with meta-analysis of patient-centered outcomes, comparing international guideline-recommended enteral protein delivery with usual care. JPEN J Parenter Enter Nutr. 2020;44:610-20.

84. Casaer MP, Mesotten D, Hermans G, Wouters PJ, Schetz M, Meyfroidt G, et al. Early versus late parenteral nutrition in critically ill adults. N Engl J Med. 2011;365:506-17.

85. Casaer MP, Wilmer A, Hermans G, Wouters PJ, Mesotten D. Role of disease and macronutrient dose in the randomized controlled EPaNIC trial: a post hoc analysis. Am J Respir Crit Care Med. 2013;187:247-55.

86. Vanhorebeek I, Verbruggen S, Casaer MP, Gunst J, Wouters PJ, Hanot J, et al. Effect of early supplemental parenteral nutrition in the paediatric ICU: a preplanned observational study of post-randomisation treatments in the PEPaNIC trial. Lancet Respir Med. 2017;5:475-83.

87. Koekkoek W, van Setten C, Olthof LE, Kars J, van Zanten ARH. Timing of PROTein INtake and clinical outcomes of adult critically ill patients on prolonged mechanical VENTilation: The PROTINVENT retrospective study. Clin Nutr. 2019;38:883-90.

88. Badjatia N, Sanchez S, Judd G, Hausladen R, Hering D, Motta M, et al. Neuromuscular electrical stimulation and high-protein supplementation after subarachnoid hemorrhage: a single-center phase 2 randomized clinical trial. Neurocrit Care. 2021;35:46-55.

89. Heyland DK, Day A, John Clarke G, Hough C, Clark Files D, Mourtzakis M, et al. Nutrition and Exercise in Critical Illness Trial (NEXIS Trial): a protocol of a multicentred, randomised controlled trial of combined cycle ergometry and amino acid supplementation commenced early during critical illness. BMJ Open. 2019;9:27893.
90. Van Zanten ARH, De Waele E, Wischmeyer PE. Nutrition therapy and critical illness: practical guidance for the ICU, post-icu, and long-term convalescence phases. Crit Care. 2019;23:368.

91. Heyland D, Muscedere J, Wischmeyer PE, Cook D, Jones G, Albert M, et al. A randomized trial of glutamine and antioxidants in critically ill patients. N Engl J Med. 2013;368:1489-97.

92. Viana MV, Becce F, Pantet $\mathrm{O}$, et al. Impact of $\beta$-hydroxy- $\beta$ methylbutyrate (HMB) on muscle loss and protein metabolism in critically ill patients: a RCT. Clin Nutr. 2021;40:4878-87.

93. Shenkin A. Functions and deficiency states of trace elements and vitamins. In: Sobotka editor. Basics Clin Nutr ESPEN. Prague: Galen; 2019. p. 123-33.

94. Gombart AF, Pierre A, Maggini SA. Review of micronutrients and the immune system-working in harmony to reduce the risk of infection. Nutrients. 2020;12:236.

95. Berger MM, Pantet O, Schneider A, Ben-Hamouda N. Micronutrient deficiencies in medical and surgical inpatients. J Clin Med. 2019;8:931.

96. Wesselink E, Wac K, Grefte S, Witkamp RF, van Zanten ARH. Feeding mitochondria: potential role of nutritional components to improve critical illness convalescence. Clin Nutr. 2019;38:982-95.

97. Berger MM, Ben-Hamouda N. Trace element and vitamin deficiency: quantum medicine or essential prescription? Curr Opin Crit Care. 2020;26:355-62.

98. Wiesen P, Van Overmeire L, Delanaye P, Dubois B, Preiser J-C. Nutrition disorders during acute renal failure and renal replacement therapy. JPEN J Parenter Enteral Nutr. 2011;35:217-22.

99. Berger MM, Broman M, Forni L, Osterman M, De Waele E, Wischmeyer PE. Nutrients and micronutrients at risk during renal replacement therapy: a scoping review. Curr Opin Crit Care. 2021;2021:26.

100. Viana MV, Pantet O, Bagnoud G, Martinez A, Favre E, Charriere M, et al. Metabolic and nutritional characteristics of long-stay critically ill patients. J Clin Med. 2019;8:985.

101. Vankrunkelsven W, Gunst J, Amrein K, Bear DE, Berger MM, Christopher $\mathrm{KB}$, et al. Monitoring and parenteral administration of micronutrients, phosphate and magnesium in critically ill patients: The VITA-TRACE Survey. Clin Nutr. 2021;40:590-9.

102. Azoulay E, Vincent JL, Angus DC, Arabi YM, Brochard L, Brett SJ, Dos Santos CC, et al. Recovery after critical illness: putting the puzzle together-a consensus of 29. Crit Care. 2017;21:296.

103. Institute of Medicine Standing Cl. Dietary reference intakes for thiamin, riboflavin, niacin, vitamin B6, folate, vitamin B12, pantothenic acid, biotin, and choline. In: Washington: US NAP. (DC); 1998.

104. Brannon PM, Weaver CM, Anderson CA, Donovan SM, Murphy SP. Scanning for new evidence to prioritize updates to the dietary reference intakes: case studies for thiamin and phosphorus. Am J Clin Nutr. 2016;104:1366-77.

105. Casaer MP, Bellomo R. Micronutrient deficiency in critical illness: an invisible foe? Intensive Care Med. 2019;45:1136-9.

106. Berger MM, Soguel L, Schindler C, Revelly JP. Antioxidant supplements modulate clinical course after complex cardiac surgery—-preliminary data. Clin Nutr. 2004;23:825.

107. Preiser JC. Oxidative stress. JPEN J Parenter Enteral Nutr. 2012;36:147-54.

108. van Zanten ARH. Nutritional support and refeeding syndrome in critical illness. Lancet Respir Med. 2015;3:904-5.

109. Koekkoek WAC, Van Zanten ARH. Is refeeding syndrome relevant for critically ill patients? Curr Opin Clin Nutr Metab Care. 2018;21:130-7.

110. Boot R, Kwac K, van Zanten ARH. Refeeding syndrome relevance for the critically ill patient. Curr Opin Crit Care. 2018;24:235-40.

111. Reintam Blaser $A$, van Zanten ARH. Electrolyte disorders during the initiation of nutrition therapy in the ICU. Curr Opin Clin Nutr Metab Care Mar. 2021;1:151-8.

112. Reintam Blaser A, Gunst J, Ichai C, et al. Hypophosphatemia in critically ill adults and children—a systematic review. Clin Nutr. 2021;40:1744-54.

113. Berger MM, Appelberg O, Reintam-Blaser A, et al. Prevalence of hypophosphatemia in the ICU—results of an international one-day point prevalence survey. Clin Nutr. 2021;40:3615-21.

114. Olthof LE, Koekkoek WACK, van Setten C, Kars JCN, van Blokland D, van Zanten ARH. Impact of caloric intake in critically ill patients with, and without, refeeding syndrome: a retrospective study. Clin Nutr. 2018;37:1609-17. 
115. Doig GS, Simpson F, Heighes PT, Bellomo R, Chesher D, Caterson ID, Harrigan PW, et al. Refeeding Syndrome Trial Investigators Group. Restricted versus continued standard caloric intake during the management of refeeding syndrome in critically ill adults: a randomised, parallel-group, multicentre, single-blind controlled trial. Lancet Respir Med. 2015;3:943-52.

116. Mehanna HM, Moledina J, Travis J. Refeeding syndrome: what it is, and how to prevent and treat it. BMJ. 2008;336:1495-8.

117. https://www.criticalcarenutritionacademy.eu/wp-content/uploads/ 2019/10/Figure-1.pdf.

118. McClave SA, Gualdoni J, Nagengast A, Marsano LS, Bandy K, Martindale RG. Gastrointestinal dysfunction and feeding intolerance do we need an objective scoring system? Curr Gastroenterol Rep. 2020;22:1.

119. Reintam Blaser A, Starkopf J, Kirsimagi U, Deane AM. Definition, prevalence, and outcome of feeding intolerance in intensive care: a systematic review and meta-analysis. Acta Anaesthesiol Scand. 2014;58(8):914-22.

120. Arabi YM, Reintam Blaser A, Preiser J-C. When and how to manage enteral feeding intolerance? Intensive Care Med. 2019;45:1029-31.

121. Heyland DK, Ortiz A, Stoppe C, Patel JJ, Yeh DD, Dukes G, et al. Incidence, risk factors, and clinical consequence of enteral feeding intolerance in the mechanically ventilated critically ill: an analysis of a multicenter. Multiyear Database Crit Care Med. 2021;49:59.

122. Gungabissoon U, Hacquoil K, Bains C, Irizarry M, Dukes G, Williamson $\mathrm{R}$, et al. Prevalence, risk factors, clinical consequences, and treatment of enteral feed intolerance during critical illness. JPEN J Parenter Enter Nutr. 2015:39:41-448.

123. Hu B, Sun R, Wu A, Ni Y, Liu J, Guo F, et al. Severity of acute gastrointestinal injury grade is a predictor of all-cause mortality in critically ill patients: a multicenter, prospective, observational study. Crit Care. 2017:21:188.

124. Reintam Blaser A, Malbrain ML, Starkopf J, Fruhwald S, Jakob SM, De Waele J, et al. Gastrointestinal function in intensive care patients: terminology, definitions and management. Recommendations of the ESICM working group on abdominal problems. Intensive Care Med. 2012;38:384-94

125. Montejo JC. Enteral nutrition-related gastrointestinal complications in critically ill patients: a multicenter study. Nutr Metab Work Gr Spanish Soc Intensive Care Med Coron Units Crit Care Med. 1999;27:1447-53.

126. Elke G, Felbinger TW. Gastric residual volume in critically ill patients: a dead marker or still alive? Nutr Clin Pract. 2015;30:59-71.

127. Reignier J, Mercier E, Le Gouge A, Boulain T, Desachy A, Bellec F, et al. Effect of not monitoring residual gastric volume on risk of ventilatorassociated pneumonia in adults receiving mechanical ventilation and early enteral feeding: a randomized controlled trial. JAMA. 2013;309:249-56

128. Lew CCH, Lee ZY, Day AG, Heyland DK. Correlation between gastric residual volumes and markers of gastric emptying: a post hoc analysis of a randomized clinical trial. JPEN J Parenter Enteral Nutr. 2021. https:// doi.org/10.1002/jpen.2234.

129. Montejo JC, Minambres E, Bordeje L, Mesejo A, Acosta J, Heras A, et al. Gastric residual volume during enteral nutrition in ICU patients: the REGANE study. Intensive Care Med. 2010;36:1386-93.

130. McClave SA, Lukan JK, Stefater JA, Lowen CC, Looney SW, Matheson PJ, et al. Poor validity of residual volumes as a marker for risk of aspiration in critically ill patients. Crit Care Med. 2005;33:324-30.

131. Reintam Blaser A, Padar M, Mändul M, et al. Development of the Gastrointestinal Dysfunction Score (GIDS) for critically ill patients-a prospective multicenter observational study (iSOFA study). Clin Nutr. 2021:40:4932-40

132. Metheny NA, Mills AC. Monitoring for intolerance to gastric tube feedings: a national survey. Am J Crit Care. 2012;21:33-40.

133. Heinonen T, Ferrie S, Ferguson C. Gut function in the intensive care unit-What is "normal"? Aust Crit Care. 2020;33:151-4.

134. Lewis K, Alqahtani Z, McIntyre L, Almenawer S, Alshamsi F, Rhodes A, et al. The efficacy and safety of prokinetic agents in critically ill patients receiving enteral nutrition: a systematic review and meta-analysis of randomized trials. Crit Care. 2016;20:259.

135. Reintam Blaser A, Deane AM, Preiser JC, Arabi YM. Enteral feeding intolerance: updates in definitions and pathophysiology. Nutr Clin Pract. 2021:36:40-9.
136. Reintam Blaser A, Preiser JC, Fruhwald S, Wilmer A, Wernerman J, Benstoem C, et al. Gastrointestinal dysfunction in the critically ill: a systematic scoping review and research agenda proposed by the section of metabolism, endocrinology and nutrition of the European Society of Intensive Care Medicine. Crit Care. 2020;24:224.

\section{Publisher's Note}

Springer Nature remains neutral with regard to jurisdictional claims in published maps and institutional affiliations.
Ready to submit your research? Choose BMC and benefit from:

- fast, convenient online submission

- thorough peer review by experienced researchers in your field

- rapid publication on acceptance

- support for research data, including large and complex data types

- gold Open Access which fosters wider collaboration and increased citations

- maximum visibility for your research: over $100 \mathrm{M}$ website views per year

At BMC, research is always in progress.

Learn more biomedcentral.com/submissions 